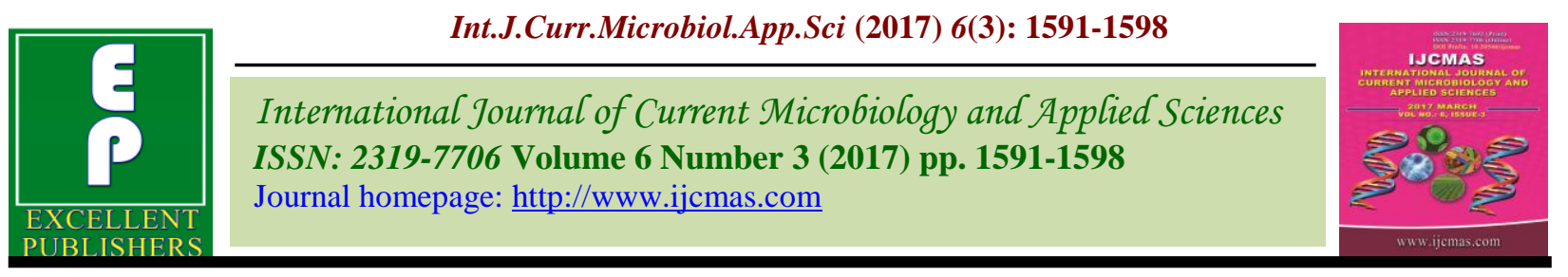

Original Research Article https://doi.org/10.20546/ijcmas.2017.603.183

\title{
In vitro Evaluation of Bio-Agents and Fungicides against Foot Rot Pathogen (Sclerotium rolfsii Sacc.) of Tomato
}

\author{
Sahana N. Banakar*, V.B. Sanath Kumar and A.G. Thejesha \\ Department of Plant Pathology, College of agriculture, V. C Farm Mandya, \\ UAS, Bengaluru, India \\ *Corresponding author
}

\section{A B S T R A C T}

Keywords

Sclerotium rolfsii, In vitro, Fungicides, Bioagents, Dual culture technique and poison food technique.

Article Info

Accepted:

22 February 2017

Available Online:

20 March 2017
Foot rot of tomato is an important disease which causes severe loss in tomato production. The present study was carried out to evaluate five bioagents and six fungicides against Sclerotium rolfsii. Among the five antagonists tested the maximum inhibition was observed in Trichoderma virens (67\%) and contrarily, no inhibition was observed in Bacillus subtilis. Six fungicides viz., carbendazim, captan, tebuconozole, copper oxychloride, hexaconozole and Tebuconazole + Trifloxytrobin at different concentrations (50, 100, 150, 200, 250 and $500 \mathrm{ppm}$ ), were tested. Among the tested fungicides, systemic fungicides like hexaconazole, tebuconozole and combi product, Nativo (tebuconazole $50 \%+$ trifloxystrobin $25 \%$ ) showed complete inhibition of $S$. rolfsii at all the concentration tested.

\section{Introduction}

Tomato (Solanum lycopersicum L.) is an important nutritive rich and warm season vegetable crop grown throughout the world.Tomato suffers from a number of fungal, bacterial, nematode and many viral diseases. The annual loss of vegetable due to the pathogen is 10 per cent, major loss is due to the fungal pathogen. Among the phytopathogenic fungi, disease caused by Sclerotium rolfsii, a soil borne fungi which causes foot rot or collar rot of tomato is gaining a serious status. $S$. rolfsii is polyphagous and most destructive soil borne fungus and was first reported by Rolfs (1892) as a cause of tomato blight in Florida. Later, Saccardo (1911) named the fungus as
Sclerotium rolfsii. But, in India the root rot caused by this pathogen was first reported by Shaw and Ajrekar (1915) who had isolated the pathogen from rotting potatoes which they identified as Rhizoctonia destruens Tassi. Later studies convinced Ajrekar that the fungus involved in rotting of potato was Sclerotium rolfsii but not $R$. destruens (Ramakrishnan, 1930). The disease is also referred as Sclerotium blight, Sclerotium wilt, southern blight, southern stem rot and white mold which cause $55-95 \%$ mortality of the crop at seedling stage under condusive conditions (Gurha and Dubey 1982). Among the phytopathogenic fungi, disease caused by Sclerotium rolfsii, a soil borne fungi which 
causes foot rot or collar rot of tomato is gaining a serious status. $S$. rolfsii has become a major limiting factor and the challenging to both farmers and scientists. Many approaches have been exploited for management of this disease, like cultural practices. Owing to soil borne nature of the pathogen and its wide host range management through chemicals as well as bio-agents is important. Keeping this in view present investigation was carried to know the effect of bio-agents and fungicides against $S$. rolfsii in vitro.

\section{Materials and Methods}

Tomato plants showing the typical symptoms of foot rot were collected and isolation of the fungus was done by following standard tissue isolation technique. Pure culture was transferred to PDA slants periodically for further studies. In vitro evaluation was carried out with five bio-agents viz., Trichoderma viride, T. harzianum, T. virens, Pseudomonas fluorescens, Bacillus subtilis against $S$. rolfsii through dual culture technique.

Dual culture technique: It was followed for the in vitro screening of bio-agents. Twenty $\mathrm{ml}$ of sterilized and cooled potato dextrose agar was poured into sterile Petri plates and allowed to solidify. For evaluation of fungal bio-control agents, mycelial disc of test fungus was inoculated at one end of the Petri plate and antagonistic fungus was placed opposite to it on the other end. In case of bacterial antagonist two mycelial discs of pathogen were inoculated at the periphery of the Petri plate and bacterial antagonist was streaked in the center of the same plate. Three replications were maintained for each treatment. The plates were incubated at $27 \pm 1^{\circ} \mathrm{C}$. After required period of incubation i.e when the growth in control plate recorded $90 \mathrm{~mm}$ in diameter, the radial growth of the pathogens was measured and zone of inhibition was recorded by measuring the clear distance between the margin of the test fungus and antagonistic organism. The per cent inhibition of growth of the pathogen was calculated by using the formula suggested by Vincent (1947).

$$
I=\frac{C-T}{C} \times 100
$$

Where,

$\mathrm{I}=$ per cent inhibition

$\mathrm{C}=$ growth in control

$\mathrm{T}=$ growth in treatment

Poisoned food technique: The efficacy of six fungicides viz., carbendazim, captan, tebuconozole, copper oxychloride, hexaconozole and Tebuconazole +Trifloxytrobin at different concentrations (50, 100, 150, 200, 250 and $500 \mathrm{ppm})$, were assayed against Sclerotium rolfsii. These fungicides were evaluated by using "Poison food technique" under laboratory conditions (Grover and Moore, 1962). Required quantity of individual fungicide was added separately into sterilized molten and cooled potato dextrose agar so as to get the desired concentration of the fungicides. Three replications were maintained for each concentration. Inoculated plates were incubated at room temperature and the radial growth was measured when fungus attained maximum growth in control plates. The efficacy of the fungicides was expressed as per cent inhibition of mycelial growth over control, which was calculated by using the formula given by Vincent (1947).

\section{Results and Discussion}

\section{In vitro evaluation of bio-agents against Sclerotium rolfsii}

The results, thus obtained (Table 1 and Plate 1) revealed that, maximum inhibition of 
mycelia growth $(67 \%)$ was recorded in Trichoderma virens after four days of incubation. Other bio-agents viz., Trichoderma viride and Trichoderma harzianum recorded $61 \%$ and $44 \%$ inhibition respectively. However $B$. subtilis did not show any inhibition of mycelial growth of $S$. rolfsii as the pathogen over grew the bioagents.

Similarly after eight days of inoculation, Trichoderma virens showed highest inhibition (70\%) followed by Trichoderma viride (63\%).Whereas Pseudomonas fluorescens and Trichoderma harzianum recorded $12 \%$ and $44 \%$ inhibition respectively. Trichoderma harzianum did not show variation in the per cent inhibition as the incubation time was increased.

Biological control is a potential non-chemical, effective and eco friendly means for plant disease management. In the present investigation the efficacy of bio-agents against $S$. rolfsii was assessed by the dual culture technique. The present study is confirmatory with the observations made by Iqbal et al. (1995), Virupaksha Prabhu et al. (1997) and Kulkarni (2007). This might be due to the production of antibiotics, which diffused, air filled pores, which are detrimental to the growth of $S$. rolfsii. and also may be due to higher competitive ability of Trichoderma spp.

\section{In vitro evaluation of fungicides against Sclerotium rolfsii}

The result revealed that, among the systemic fungicides hexaconozole and tebuconozole were found to be highly effective at all concentrations tested and these inhibited cent per cent mycelia growth of $S$. rolfsii and were significantly superior over control (Table 2 and Plate 2).

Table.1 In vitro evaluation of bio-agents against foot rot fungus Sclerotium rolfsii

\begin{tabular}{|l|l|l|l|}
\hline \multirow{2}{*}{ Treatments } & \multicolumn{1}{|c|}{ BIOAGENTS } & \multicolumn{2}{c|}{$\begin{array}{c}\text { PER CENT INHIBITION } \\
\text { (Days after incubation) }\end{array}$} \\
\cline { 3 - 4 } & & \multicolumn{1}{c|}{$\mathbf{4}$} & \multicolumn{1}{c|}{$\mathbf{8}$} \\
\hline $\mathrm{T}_{1}$ & Trichoderma viride & $61(45.75)^{*}$ & $63(46.24)$ \\
\hline $\mathrm{T}_{2}$ & Trichoderma harzianum & $44(40.12)$ & $44(40.12)$ \\
\hline $\mathrm{T}_{3}$ & Trichoderma virens & $67(47.81)$ & $70(48.88)$ \\
\hline $\mathrm{T}_{4}$ & Pseudomonas fluorescens & $11(26.01)$ & $12(26.71)$ \\
\hline $\mathrm{T}_{5}$ & Bacillus subtilis & 0 & 0 \\
\hline & SEm \pm & $\mathbf{0 . 6 2}$ & $\mathbf{0 . 7 9}$ \\
\hline & C.D at 1\% & $\mathbf{1 . 9 2}$ & $\mathbf{2 . 4 9}$ \\
\hline
\end{tabular}

*Figures in parenthesis are arcsine transformed values 
Table.2 In vitro evaluation of botanicals against foot rot fungus Sclerotium rolfsii

\begin{tabular}{|c|c|c|c|c|c|}
\hline \multirow[t]{3}{*}{ Treatments } & \multirow{3}{*}{$\begin{array}{l}\text { Extracts of } \\
\text { Botanicals }\end{array}$} & \multicolumn{4}{|c|}{ Mean per cent mycelial inhibition } \\
\hline & & \multicolumn{4}{|c|}{ Concentration of botanicals (\%) } \\
\hline & & 5 & 10 & 15 & MEAN \\
\hline $\mathrm{T}_{1}$ & Neem leaf & $75.55(60.35)^{*}$ & $91.11(72.64)$ & $93.33(75.02)$ & $86.66(68.56)$ \\
\hline $\mathrm{T}_{2}$ & Eucalyptus leaf & $38.88(38.56)$ & $50.00(44.99)$ & $53.00(46.71)$ & $47.29(43.44)$ \\
\hline $\mathrm{T}_{3}$ & Jathropa leaf & $22.55(28.34)$ & $24.44(29.62)$ & $44.07(41.58)$ & $30.35(33.42)$ \\
\hline $\mathrm{T}_{4}$ & Tulsi leaf & $38.88(38.56)$ & $59.67(50.56)$ & $61.67(51.73)$ & $53.40(46.94)$ \\
\hline $\mathrm{T}_{5}$ & Garlic bulb & $97.77(81.40)$ & $98.88(83.91)$ & $100 \quad(89.98)$ & $98.88(83.91)$ \\
\hline $\mathrm{T}_{6}$ & Onion bulb & $100 \quad(89.98)$ & $100 \quad(89.98)$ & $100 \quad(89.98)$ & $100 \quad(89.98)$ \\
\hline \multirow[t]{4}{*}{$\mathrm{T}_{7}$} & Marigold leaf & $86.33(68.28)$ & $89.67(71.23)$ & $90.78(72.31)$ & $88.92(70.54)$ \\
\hline & & Botanicals & Concentrations & B X C & \\
\hline & SEm \pm & 0.150 & 0.139 & 0.367 & \\
\hline & C.D at $1 \%$ & 0.569 & 0.527 & 1.393 & \\
\hline
\end{tabular}

*Figures in parenthesis are arcsine transformed value 
Table.3 In vitro evaluation of fungicides against foot rot fungus Sclerotium rolfsii

\begin{tabular}{|c|c|c|c|c|c|c|c|}
\hline \multirow{3}{*}{ Treatments } & \multirow{3}{*}{ Fungicides } & \multicolumn{6}{|c|}{ Mean per cent mycelial inhibition } \\
\hline & & \multicolumn{6}{|c|}{ Concentation (ppm) } \\
\hline & & 50 & 100 & 150 & 200 & 250 & 500 \\
\hline $\mathrm{T}_{1}$ & Carbendazim (50 \% WP) & 0 & 0 & 0 & 0 & $\begin{array}{c}11.10 \\
(19.45)\end{array}$ & $\begin{array}{r}88.80 \\
(70.43)\end{array}$ \\
\hline $\mathrm{T}_{2}$ & Captan (50 \% WP) & 0 & 0 & 0 & $\begin{array}{c}11.11 \\
(19.46)\end{array}$ & $\begin{array}{c}66.66 \\
(54.72)\end{array}$ & $\begin{array}{c}100 \\
(89.98)\end{array}$ \\
\hline $\mathrm{T}_{3}$ & Tebuconazole (25.9\% EC) & $\begin{array}{c}100 * \\
(89.98)\end{array}$ & $\begin{array}{c}100 \\
(89.98)\end{array}$ & $\begin{array}{c}100 \\
(89.98)\end{array}$ & $\begin{array}{c}100 \\
(89.98)\end{array}$ & $\begin{array}{c}100 \\
(89.98)\end{array}$ & $\begin{array}{c}100 \\
(89.98)\end{array}$ \\
\hline $\mathrm{T}_{4}$ & $\begin{array}{l}\text { Copper oxychloride (50\% } \\
\text { WP) }\end{array}$ & 0 & 0 & 0 & 0 & $\begin{array}{c}5.55 \\
(13.62)\end{array}$ & $\begin{array}{c}33.33 \\
(35.25)\end{array}$ \\
\hline $\mathrm{T}_{5}$ & Hexaconozole (5 \% SC) & $\begin{array}{c}100 \\
(89.98)\end{array}$ & $\begin{array}{c}100 \\
(89.98)\end{array}$ & $\begin{array}{c}100 \\
(89.98)\end{array}$ & $\begin{array}{c}100 \\
(89.98)\end{array}$ & $\begin{array}{c}100 \\
(89.98)\end{array}$ & $\begin{array}{c}100 \\
(89.98)\end{array}$ \\
\hline $\mathrm{T}_{6}$ & $\begin{array}{l}\text { Tebuconazole }+ \\
\text { Trifloxystrobin }(50 \%+25 \% \\
\text { WG) }\end{array}$ & $\begin{array}{c}100 \\
(89.98)\end{array}$ & $\begin{array}{c}100 \\
(89.98)\end{array}$ & $\begin{array}{c}100 \\
(89.98)\end{array}$ & $\begin{array}{c}100 \\
(89.98)\end{array}$ & $\begin{array}{c}100 \\
(89.98)\end{array}$ & $\begin{array}{c}100 \\
(89.98)\end{array}$ \\
\hline & & Fungicide & COC. & $\mathbf{F} \times \mathbf{C}$ & & & \\
\hline & SEm \pm & 0.122 & 0.113 & 0.30 & & & \\
\hline & C.D at $1 \%$ & 0.45 & 0.422 & 1.117 & & & \\
\hline
\end{tabular}

\footnotetext{
*Figures in parenthesis are arcsine transformed value
} 
Plate.1 Effect of bio-agents on the mycelia growth of Sclerotium rolfsii on tomato

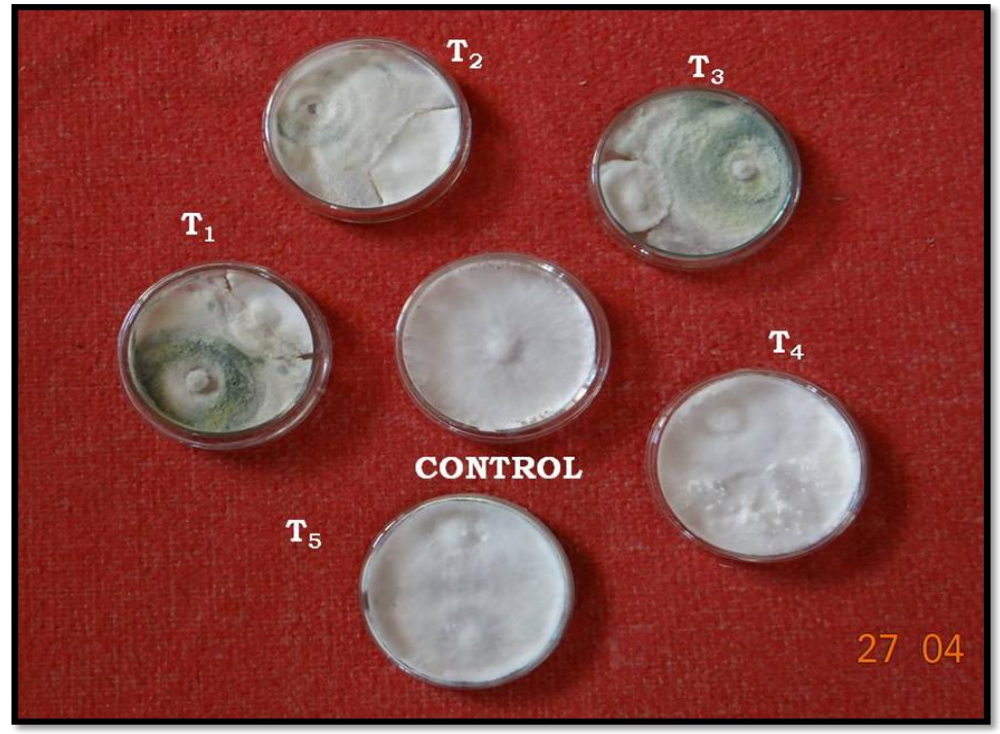

\section{Legend:}

$\mathbf{T}_{1}:$ Trichoderma viride

$\mathbf{T}_{2}$ : Trichoderma harzianum

$\mathbf{T}_{3}$ : Trichoderma virens

$\mathbf{T}_{\mathbf{4}}$ : Pseudomonas fluorescens

$\mathbf{T}_{5}$ : Bacillus subtilis

Plate.2 Effect of fungicides on the mycelia growth of Sclerotium rolfsii on tomato

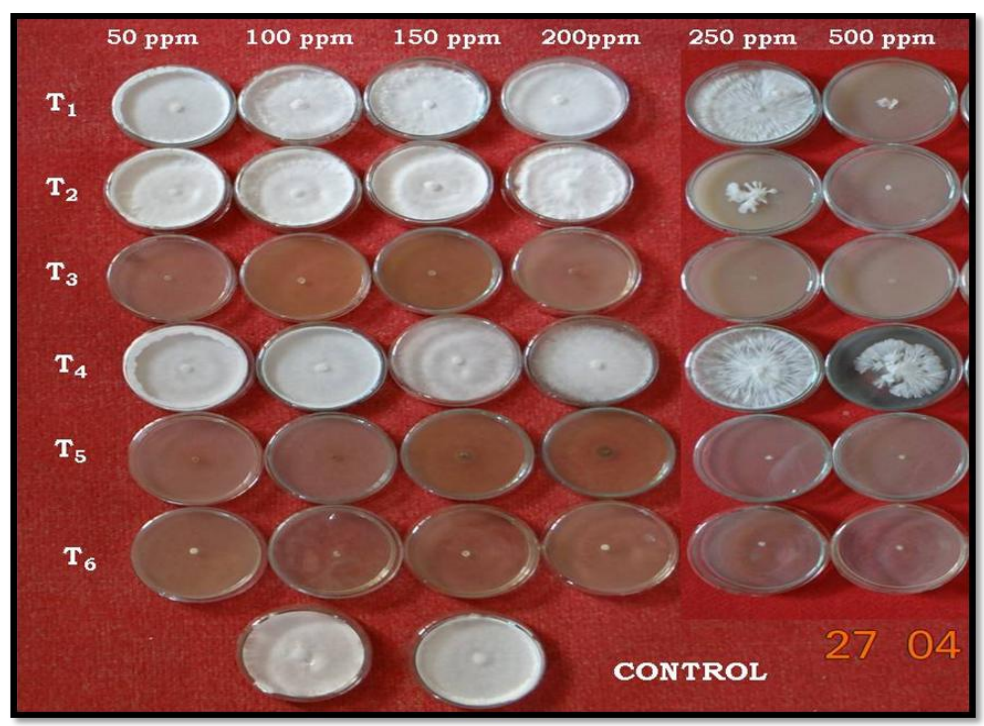

\section{Legend:}

$\mathbf{T}_{1}$ : Carbendazim

$\mathbf{T}_{2}$ : Captan

$\mathbf{T}_{3}$ : Tebuconazole

$\mathbf{T}_{\mathbf{4}}$ : Copperoxichloride

$\mathbf{T}_{5}$ : Hexaconozole

$\mathbf{T}_{\mathbf{6}}$ : Tebuconazole 50\% + Trifloxystrobin 25\% (Nativo) 
Carbendazim does not show any inhibition of the mycelial growth of Sclerotium rolfsii at 50, 100, 150 and $200 \mathrm{ppm}$ and it was comparable to control. However at $250 \mathrm{ppm}$ and $500 \mathrm{ppm}$ pathogen was inhibited by 11.10 and 88.80 per cent respectively. Non-systemic fungicide, captan was highly effective at higher concentration as it inhibited the mycelial growth Sclerotium rolfsii up to 66.66 and 100 per cent at 250 and 500 ppm respectively. However it does not showed any inhibition at lower concentrations $(50,100$ and $150 \mathrm{ppm}$ ). Copper oxychloride (COC) was found to be least effective in inhibiting the growth of Sclerotium rolfsii as it inhibited only 5.55 and 33.33 per cent at 250 and 500 ppm respectively, where as combi product, tebuconazole $50 \%+$ trifloxystrobin $25 \%$ (Nativo) showed cent per cent inhibition at all the concentration tested (Table 3).

The results of present investigation are in confirmatory with the findings of earlier workers. Sharma and Verma (1985); Kulkarni (2007), Johnson and Subramanyam (2000) and Arunasri et al. (2011) reported that the triazoles (hexaconazole, propiconazole, difenconazole) and combi products containing triazoles viz., Avatar, Merger and Nativo were highly inhibitive to the growth of Sclerotium rolfsii. In the present study the effective fungicides viz., triazoles and tebuconozole + trifloxystrobin probably may act as antifungal agents and imparts its poisoning effect on metabolic process of pathogen, therefore, the growth of the $S$. rolfsii might be adversely affected. The present findings suggest that the Trichoderma spp and systemic fungicides have direct effect on the foot rot causing fungi S. rolfsii.

\section{References}

Arunasri, P., Chalam T. V., Eswara, Reddy N. P., Tirumala R. and Ravindra R. B., 2011. Investigations on fungicidal sensitivity of Trichoderma spp. and Sclerotium rolfsii (collar rot pathogen) in crossandra. Inter. J. Appl. Bio. Pharm. Tech., 2(2): 290-293.

Bhagwat, R. V., 1997. Studies on foot rot of sunflower (Helianthus annuus L.) caused by Sclerotium rolfsii Sacc. $M$. Sc. (Agri.) Thesis, Univ. of Agric. Sci., Dharwad, 42-44. pp.

Basamma, 2008. Integrated management of Sclerotium wilt of potato caused by Sclerotium rolfsii Sacc. M. Sc. (Agri.) Thesis, Univ. Agric. Sci., Dharwad, 113. pp.

Chowdhury, K. A., Reddy, D. R. and Rao K. C., 1998. Efficiency of systemic (triazoles) and non-systemic fungicides against Sclerotium wilt of bell pepper caused by Sclerotium rolfsii Sacc. Indian J. Pl. Protect., 26:125-130.

Grover, R. K. and Moore, J. D., 1962. Toxicometric studies of fungicides against brown rot organisms Sclerotinia fructicola and S. laxa. Phytopathology, 52: 876- 880.

Iqbal, S. M., Bathsh, S. Hussain and Malik, B. A., 1995. Microbial antagonism against Sclerotium rolfsii the cause of collar rot of lentil. Lens News., 22: 4449.

Jabbar Sab, 2013. Studies on collar rot of chick pea caused by Sclerotium rolfsii Sacc. M. Sc. (Agri.) Thesis, Univ. Agric. Sci., Bengaluru.

Johnson, M and Subramanyam, 2000. In vitro efficiency of fungicides against stem rot pathogen of groundnut. Ann. Pl. Prot. Sci., 8: 255-257.

Karthikeyan, A., 1996. Effect of organic amendments, antagonistic Trichoderma viride and fungicides on seed and collar rot of groundnut. Plant Dis. Res., 11: 72-74.

Kulkarni, V. R., 2007. Epidemiology and integrated management of potato wilt 
caused by Sclerotium rolfsii Sacc. Ph. D. Thesis, Univ. Agric. Sci., Dharwad, 191. pp.

Manu, T. G., 2012. Studies on Sclerotium rolfsii (Sacc.) causing foot rot disease on finger millet M.Sc. (Agri.) Thesis, Univ. Agric. Sci., Bangalore, 76. pp.

Ramakrishnan, T. S., 1930. A wilt of zinnia caused by Sclerotium rolfsii. Madras Agric. J., 16: 511-519.

Rolfs, P. H., 1892. Tomato blight some hints, Bulletin of Florida Agricultural Experimental Station, 18. pp.

Saccardo, P. A., 1911. Notae mycologicae. Annales Mycologici, 9: 249-257.

Sharma, J. P and Verma R. N., 1985. Effect of various concentrations of fungicides in vitro on Sclerotium rolfsii. Indian Phytopath., 38: 358- 360.

Shaw, F. J. P. and Ajrekar, S. L., 1915. The genus Rhizoctonia in India. Mem.
Department of Agricultural Indian Bot. Ser., 7: 177-194.

Upadhyay, J. P. and Mukhopadhyya, A. N., 1983. Effect of non-volatile and volatile antibiotics of Trichoderma harzianum on the growth of Sclerotium rolfsii. Indian J. Mycol. Pl. Pathol., 13: 232-233.

Vincent, J. M., 1947. Distortion of fungal hyphae in the presence of certain inhibitors. Nature, 150: 850.

Virupaksha Prabhu, H and Hiremath, P. C., 2003. Bioefficacy of fungicides against collar rot of cotton caused by Sclerotium rolfsii Sacc. Karnataka J. Agric. Sci., 16(4): 576-579.

Virupaksha Prabhu, H., Hiremath, P. C. and Patil, M. S., 1997. Biological control of collar rot of cotton caused by Sclerotium rolfsii Sacc. Karnataka J. Agric. Sci., 10: 397-4

\section{How to cite this article:}

Sahana N. Banakar, V.B. Sanath Kumar and Thejesha, A.G. 2017. In vitro Evaluation of BioAgents and Fungicides against Foot Rot Pathogen (Sclerotium rolfsii Sacc.) of Tomato. Int.J.Curr.Microbiol.App.Sci. 6(3): 1591-1598. doi: https://doi.org/10.20546/ijcmas.2017.603.183 